\title{
De novo facioscapulohumeral muscular dystrophy defined by DNA probe p13E-11 (D4F104S1)
}

Clinical Genetics, Institute of Child Health, Bristol P E Jardine P W Lunt

Medical Centre for Human Genetics, University of Marburg, Marburg, Germany M C Koch

K D Bathke

Institute of Medical Genetics, Cardiff J Maynard

P S Harper

M Upadhyaya

Correspondence to: Dr P E Jardine, Department of Neurology, Booth Hall of Neurology, Booth Children's Hospital, Manchester M9 2AA. Accepted 8 June 1994

\author{
P E Jardine, M C Koch, P W Lunt, J Maynard, K D Bathke, P S Harper, M Upadhyaya
}

\begin{abstract}
Facioscapulohumeral muscular dystrophy (FSHD) is an autosomal dominant condition with variable age of onset and severity. Identification of a de novo DNA fragment by probe p13E-11 (D4F104S1) established the diagnosis of new mutation FSHD in 27 of 31 sporadic cases. The clinical data for these certain new mutation cases were as follows: 13 boys, 14 girls; mean age of onset 6.8 years; significant leg weakness in $19 / 27(70 \%)(8 / 27$ $(30 \%)$ used wheelchairs at a mean age of $17 \cdot 7$ years); high tone sensorineural deafness in 10/27; visual acuity and direct ophthalmoscopy were normal. Congenital facial diplegia and sensorineural deafness in three children suggest that infantile FSHD is not a genetically separate disorder from FSHD. Ascertainment bias may explain the difference in severity between this group and typical familial cases. Molecular analysis for FSHD should be considered in children with either congenital or early onset facial weakness or diplegia.
\end{abstract}

(Arch Dis Child 1994; 71: 221-227)

Facioscapulohumeral muscular dystrophy (FSHD) is an autosomal dominant disorder with widely variable clinical presentation. The age of onset may vary from childhood to late adult life with most presenting in adolescence. A few obligate heterozygotes may be entirely asymptomatic, but careful examination shows the gene to have almost complete age dependent penetrance by the age of 20 years. ${ }^{1}$ Symptomatic onset is usually with shoulder girdle weakness, but asymptomatic facial weakness, manifesting as weakness of eye closure or cheek puff and inability to whistle often precedes this. Most patients develop significant lower limb weakness, with $19 \%$ over 40 years of age requiring wheelchairs. ${ }^{2}$

Early descriptions of FSHD (l'atrophie musculaire graisseuse progressive de l'enfance) by Duchenne ${ }^{3}$ and Landouzy and Dejerine ${ }^{4}$ emphasised the onset of disease in early childhood, sometimes with rapid progression. Duchenne also noted sporadic cases developing 'without hereditary cause'. ${ }^{5}$ Later workers described FSHD as a disease with an onset not earlier than 7 years $^{6}$ and with a benign course in many patients. ${ }^{7}$

In 1968 Small described four siblings with Coats' disease, FSHD, mental retardation, and deafness. ${ }^{8}$ Since then there have been a number of reports of early childhood onset FSHD, ${ }^{9-24}$ often with severe disability and sensorineural hearing loss. Coats' disease or retinal vessel tortuosity and FSHD has also been described. ${ }^{10-12} 1416$ 18-20 2425 A separate MIM number (227340) exists for FSHD with sensorineural hearing loss and tortuosity of retinal arterioles. ${ }^{26}$ Mechanisms suggested for early onset FSHD include genetic heterogeneity, ${ }^{9}$ autosomal recessive inheritance, ${ }^{23}$ inheritance of a modifying gene from one parent, ${ }^{27}$ and simultaneous inheritance of Duchenne muscular dystrophy and FSHD. ${ }^{28}$

The FSHD gene was localised by linkage analysis to the distal long arm of chromosome 4 by Wijmenga et al in $1990 .{ }^{29}$ Although most FSHD families are linked to chromosome 4, the report of one large unlinked family suggests at least one other FSHD locus. ${ }^{30} \mathrm{De}$ novo DNA rearrangements detected by probe p13E-11 have now been described in $5 / 6,31$ $9 / 10,{ }^{32}$ and $7 / 8^{33}$ sporadic cases of FSHD. This rearrangement is identifiable on Southern blots as a new smaller sized band in the sporadic case which is not present in either unaffected parent. Deletion of integral copies of a $3.2 \mathrm{~kb}$ tandemly repeated unit may be the cause of this rearrangement, ${ }^{34}$ the size of which can be assessed by pulsed field gel electrophoresis. ${ }^{35}$ Probe p13E-11 therefore offers a diagnostic test for new mutation FSHD, if DNA is available from the index case and both parents, which we have used to define a molecularly homogenous group of children with FSHD. Deletion size data on the patients in this series will be reported separately.

\section{Patients and methods}

PATIENTS

A total of 31 sporadic cases of FSHD were ascertained (21 from the UK and 10 from Germany) by referral from neurologists, geneticists, and the patients themselves. All had symptomatic onset in childhood. Of these four did not show a de novo fragment on Southern analysis and are not discussed further in this report. Patients and their parents were examined by PEJ, PWL, MCK, or KDB. Available hospital notes were studied. If symptoms of hearing loss were present, audiometry was performed in a sound attenuating booth. Two mothers had questionable facial weakness. The parents were second cousins in case 15.15 Only two of the index cases have had children themselves (case 14, three children, two affected; case 16, six children, four affected). One of these families 
Table 1 Clinical details of patients

\begin{tabular}{|c|c|c|c|c|c|c|c|c|c|c|c|c|}
\hline $\begin{array}{l}\text { Patient } \\
\text { No }\end{array}$ & $\operatorname{Sex}$ & $\begin{array}{l}\text { Age of } \\
\text { onset } \\
\text { (years) }\end{array}$ & $\begin{array}{l}\text { Presenting } \\
\text { symptoms }\end{array}$ & $\begin{array}{l}\text { Previous } \\
\text { diagnosis }\end{array}$ & $\begin{array}{l}\text { Age at } \\
\text { examination }\end{array}$ & $\begin{array}{l}\text { Distribution } \\
\text { of muscle } \\
\text { weakness* }\end{array}$ & $\begin{array}{l}\text { Age to } \\
\text { wheelchair } \\
\text { (years) }\end{array}$ & $\begin{array}{l}\text { Pseudo- } \\
\text { hypertrophy }\end{array}$ & $\begin{array}{l}\text { Fixed } \\
\text { deformities* }\end{array}$ & Hearing loss & $\begin{array}{l}\text { Muscle } \\
\text { biopsy }\end{array}$ & $\begin{array}{l}\text { Fragment } \\
\text { size } \\
\text { (kb) }\end{array}$ \\
\hline 1 & $\mathbf{F}$ & $<1$ & $\begin{array}{l}\text { Facial } \\
\quad \text { asymmetry }\end{array}$ & $\begin{array}{l}\text { ?Facial nerve } \\
\text { palsy }\end{array}$ & 20 & FSLP & & No & $S$ & $\begin{array}{l}\text { High frequency } \\
\text { loss between } \\
4000 \text { and } 6000 \\
\mathrm{~Hz} \text { in left ear }\end{array}$ & ND & 14 \\
\hline 2 & $\mathbf{M}$ & $<1$ & $\begin{array}{l}\text { Facial diplegia, } \\
\text { neonatal } \\
\text { hypotonia }\end{array}$ & $\begin{array}{c}\text { Congenital } \\
\text { myotonic } \\
\text { dystrophy }\end{array}$ & 17 & FSLP & 11 & $\begin{array}{l}\text { Quadriceps } \\
\text { and calves }\end{array}$ & $\mathrm{L}, \mathrm{S}$ & $80 \mathrm{~dB}$ bilateral loss & FV, II & 16 \\
\hline 3 & $\mathbf{F}$ & $<1$ & $\begin{array}{l}\text { Facial weakness, } \\
\text { neonatal } \\
\text { hypotonia }\end{array}$ & & 9 & FSLP & & No & L & $\begin{array}{l}\text { Notch at } 6000 \mathrm{~Hz} \\
\text { left ear }\end{array}$ & ND & 13 \\
\hline 4 & $\mathbf{F}$ & 1 & Facial weakness & ?Polymyositis & 24 & FSLP & & No & $\mathrm{L}, \mathrm{S}$ & Not symptomatic & $\begin{array}{c}\text { 1P, 2A, } \\
\text { FN }\end{array}$ & 13 \\
\hline 5 & $\mathbf{M}$ & 1 & Abnormal gait & & 16 & FSLP & 15 & No & $\mathrm{L}, \mathrm{S}$ & $\begin{array}{l}\text { Not symptomatic, } \\
\text { high tone notch } \\
\text { on audiogram }\end{array}$ & ND & 18 \\
\hline $\begin{array}{l}6 \\
7\end{array}$ & $\begin{array}{l}\mathbf{M} \\
\mathbf{F}\end{array}$ & $\begin{array}{r}<2 \\
2\end{array}$ & $\begin{array}{l}\text { Facial weakness } \\
\text { Facial weakness }\end{array}$ & & $\begin{array}{l}24 \\
23\end{array}$ & $\begin{array}{l}\text { FSLP } \\
\text { FSL }\end{array}$ & & $\begin{array}{l}\text { Calves } \\
\text { No }\end{array}$ & L & $\begin{array}{l}\text { Not symptomatic } \\
\text { Not symptomatic }\end{array}$ & $\begin{array}{l}1 \mathrm{~A}, 2 \mathrm{~A} \\
\mathrm{ND}\end{array}$ & $\begin{array}{l}29 \\
19\end{array}$ \\
\hline 8 & $\mathbf{M}$ & 2 & Facial weakness & Facial palsy & 20 & FSLP & 17 & No & $S$ & $\begin{array}{l}\text { Bilateral } 60 \mathrm{~dB} \\
\text { sensorineural } \\
\text { loss }\end{array}$ & $\begin{array}{c}\text { 1P, 2A, } \\
\text { FN }\end{array}$ & 13 \\
\hline 9 & $\mathbf{F}$ & 2 & $\begin{array}{l}\text { Facial weakness, } \\
\text { neonatal hypo- } \\
\text { tonia }\end{array}$ & $\begin{array}{l}\text { Möbius' } \\
\text { syndrome }\end{array}$ & 7 & FSL & & $\begin{array}{l}\text { Pectoralis } \\
\text { major }\end{array}$ & & $\begin{array}{l}\text { High frequency } \\
\text { loss 4000-6000 } \\
\text { Hz }\end{array}$ & $\begin{array}{c}1 \mathrm{~A}, 2 \mathrm{~A} \\
\mathrm{EF}\end{array}$ & 17 \\
\hline $\begin{array}{l}10 \\
11\end{array}$ & F & $\begin{array}{l}4 \\
4\end{array}$ & $\begin{array}{l}\text { Leg weakness } \\
\text { Facial weakness }\end{array}$ & SMA & $\begin{array}{l}17 \\
42\end{array}$ & $\begin{array}{l}\text { FSLP } \\
\text { FSL }\end{array}$ & $\begin{array}{r}8 \\
25\end{array}$ & No & L & $\begin{array}{l}\text { Not symptomatic } \\
\text { Bilateral } 70 \mathrm{~dB} \text { loss }\end{array}$ & $\mathbf{R}$ & $\begin{array}{l}14 \\
16\end{array}$ \\
\hline 12 & $\mathbf{F}$ & 4 & Facial weakness & & 17 & FSLP & & No & $\mathrm{L}, \mathrm{S}$ & $\begin{array}{l}\text { High frequency } \\
\text { loss between } \\
4000 \text { and } 6000 \\
\mathrm{~Hz}\end{array}$ & FN, $1 A$ & 14 \\
\hline 13 & $\mathbf{F}$ & 5 & $\begin{array}{l}\text { Shoulder and leg } \\
\text { weakness }\end{array}$ & & 20 & FSLP & 12 & No & $\mathrm{L}, \mathrm{S}$ & Bilateral $40 \mathrm{~dB}$ loss & $\begin{array}{c}\text { 1A, 2A, } \\
\text { FH, } \\
\text { FM, } \\
\text { EF }\end{array}$ & 13 \\
\hline 14 & $\mathbf{M}$ & 6 & Facial weakness & $\begin{array}{l}\text { ?Polymyositis, } \\
\text { ?Becker MD }\end{array}$ & 35 & FSLP & & Calves & $\mathbf{L}$ & Not symptomatic & FV, II & 15 \\
\hline 15 & $\mathbf{M}$ & 7 & Leg weakness & ?SMA & 16 & FSLP & & $\begin{array}{l}\text { Calf hypertro- } \\
\text { phy as a } \\
\text { child }\end{array}$ & $\mathbf{L}$ & $\begin{array}{l}\text { Not symptomatic, } \\
\text { audiogram } \\
\text { bilateral } 20 \mathrm{~dB} \\
\text { loss at } 600 \mathrm{~Hz}\end{array}$ & $\begin{array}{l}\text { IP, SA, } \\
\text { FN, } \\
\text { II }\end{array}$ & 18 \\
\hline 16 & $\mathbf{F}$ & 10 & $\begin{array}{l}\text { Shoulder } \\
\text { weakness }\end{array}$ & & 50 & FSL & & No & & Not symptomatic & ND & 17 \\
\hline 17 & $\mathbf{F}$ & 10 & Abnormal gait & & 19 & FSLP & & No & $\mathrm{L}, \mathrm{S}$ & Not symptomatic & $\begin{array}{c}\text { 1P, CN, } \\
\text { FM }\end{array}$ & 24 \\
\hline $\begin{array}{l}18 \\
19\end{array}$ & $\begin{array}{l}\mathbf{M} \\
\mathbf{M}\end{array}$ & $\begin{array}{l}10 \\
10\end{array}$ & $\begin{array}{l}\text { Facial weakness } \\
\text { Shoulder } \\
\text { weakness }\end{array}$ & & $\begin{array}{l}27 \\
25\end{array}$ & $\begin{array}{l}\text { FSLP } \\
\text { FSP }\end{array}$ & & $\begin{array}{l}\text { No } \\
\text { No }\end{array}$ & $\mathbf{L}$ & $\begin{array}{l}\text { Not symptomatic } \\
\text { Symptomatic } \\
\text { hearing loss but } \\
\text { audiometry not } \\
\text { performed }\end{array}$ & $\begin{array}{l}\text { ND } \\
\text { ND }\end{array}$ & $\begin{array}{l}17 \\
20\end{array}$ \\
\hline 20 & $\mathbf{M}$ & 11 & $\begin{array}{l}\text { Shoulder weak- } \\
\text { ness, scapular } \\
\text { winging }\end{array}$ & $\begin{array}{l}\text { ?Becker MD, } \\
\text { ?Limb girdle } \\
\text { MD }\end{array}$ & 39 & FSLP & 37 & No & $\mathbf{L}$ & Not symptomatic & ND & 23 \\
\hline 21 & $\mathbf{M}$ & 11 & $\begin{array}{l}\text { Shoulder } \\
\text { weakness }\end{array}$ & $\begin{array}{l}\text { ?Mitochondrial } \\
\text { myopathy }\end{array}$ & 19 & FSLP & 17 & Calves & $\mathbf{L}$ & $\begin{array}{l}\text { Not symptomatic, } \\
\text { normal } \\
\text { audiogram }\end{array}$ & $\begin{array}{c}\text { 1P, SA, } \\
\text { FM }\end{array}$ & 13 \\
\hline 22 & $\mathbf{M}$ & 12 & $\begin{array}{l}\text { Shoulder } \\
\text { weakness }\end{array}$ & $\begin{array}{l}\text { ?Limb girdle } \\
\text { MD }\end{array}$ & 20 & FS & & No & & Not symptomatic & $\begin{array}{c}\text { FH, 1A, } \\
2 \mathrm{~A}, \\
\text { SA }\end{array}$ & 16 \\
\hline 23 & $\mathbf{M}$ & 13 & $\begin{array}{l}\text { Shoulder } \\
\text { weakness }\end{array}$ & $\begin{array}{c}\text { Sprengel } \\
\text { deformity }\end{array}$ & 27 & FSLP & & No & & Not symptomatic & $\begin{array}{c}\text { 1A, 2A, } \\
\text { FH, } \\
\text { FN, } \\
\text { EF }\end{array}$ & 24 \\
\hline 24 & $\mathbf{M}$ & 13 & Facial weakness & & 33 & FSP & & $\begin{array}{l}\text { Deltoids and } \\
\text { quadriceps }\end{array}$ & L & Not symptomatic & ND & 16 \\
\hline 25 & $\mathbf{F}$ & 14 & $\begin{array}{l}\text { Shoulder } \\
\text { weakness }\end{array}$ & & 35 & FSLP & & No & $\mathbf{L}$ & Not symptomatic & $\mathbf{R}$ & 17 \\
\hline 26 & $\mathbf{F}$ & 15 & $\begin{array}{l}\text { Shoulder } \\
\text { weakness }\end{array}$ & & 33 & FSLP & & No & $\mathrm{L}, \mathrm{S}$ & Not symptomatic & $\begin{array}{c}\text { FH,CN, } \\
\text { SA }\end{array}$ & 20 \\
\hline 27 & $\mathbf{F}$ & 16 & $\begin{array}{l}\text { Shoulder } \\
\text { weakness }\end{array}$ & & 28 & FS & & No & L & Not symptomatic & $1 \mathbf{P}, \mathbf{F H}$ & 19 \\
\hline
\end{tabular}

${ }^{\star} M D=$ muscular dystrophy; SMA = spinal muscular atrophy; $F=$ facial; $S=$ scapulohumeral; $L=$ proximal leg; $P=$ peroneal/anterior tibial; $L=$ lumbar lordosis; $S=$ scoliosis; FN=fibre necrosis; 1A, type 1 fibre atrophy; 2A, type 2 fibre atrophy; FH, fibre hypertrophy; FM, moth eaten fibres; EF, endomysial fibrosis; FV, variation in fibre diameter; II, inflammatory infiltrate; 1P, type 1 fibre predominance; SA, small angular fibres; CN, central nuclei; ND, muscle biopsy not performed; $\mathbf{R}$, muscle biopsy said to be myopathic but no details available.

(case 14) has been reported previously 3637 showing transmission of the de novo fragment to the affected children in the next generation. Clinical details on the index patients are listed in table 1 and a detailed description of one patient follows.

CASE HISTORY

Patient 2 was the second male child of unrelated parents. Neither parent had any symptoms of shoulder girdle or leg weakness, but his mother was unable to whistle. Physical examination in her was unremarkable except for a slight flattening of the nasolabial folds and an inability to bury the eyelashes tightly. There was no other significant family history. The pregnancy and delivery were normal. At birth his face appeared immobile and he was hypotonic (fig 1). A provisional diagnosis of congenital myotonic dystrophy was made (fig 2). He sat independently at 6 months and walked at 1 year of age, although subsequent gait has always been abnormal. A lacrimal duct dilatation was undertaken at the age of 2 years because of epiphora. He was never able to hang his coat on a peg, but weakness of shoulder abduction, grip, and scapular winging 


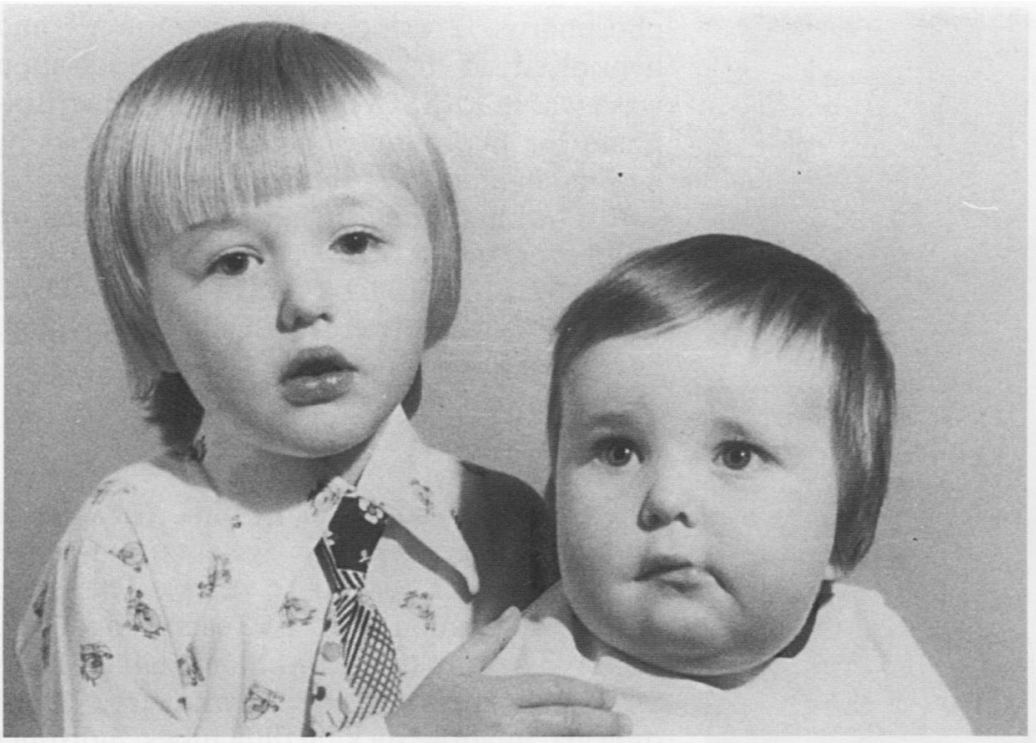

Figure 1 Aged 8 months: facial asymmetry and weakness. Normal brother on left.

were first documented at the age of 5 years. Creatine kinase was 1.4 times the upper limit of normal. Troublesome drooling and dysarthria at the age of 7 years (fig 3) were improved after plastic surgery. The electromyogram was myopathic. An initial muscle biopsy sample from the left biceps was reported as normal but a later biopsy sample from the left deltoid showed fibre necrosis and regeneration, an inflammatory infiltrate, fibre calibre variation, and a few moth eaten fibres. An audiogram at the age of 8 years showed an $80 \mathrm{~dB}$ sensorineural deafness and hearing aids were fitted. There was gradual progression of limb weakness and truncal weakness (fig 4) with requirement for a wheelchair at the age of 11 years (fig 5 ).

On examination at the age of 17 years there was wasting of the deltoids, spinati, pectorals, and upper arm muscles. The quadriceps and calves were pseudohypertrophied. He was unable to close his eyes, smile, or blow his cheeks out. Speech was indistinct. Eye movements were normal and there was no ptosis. There was scapular winging, lumbar lordosis, and mild scoliosis. The cough reflex was weak.

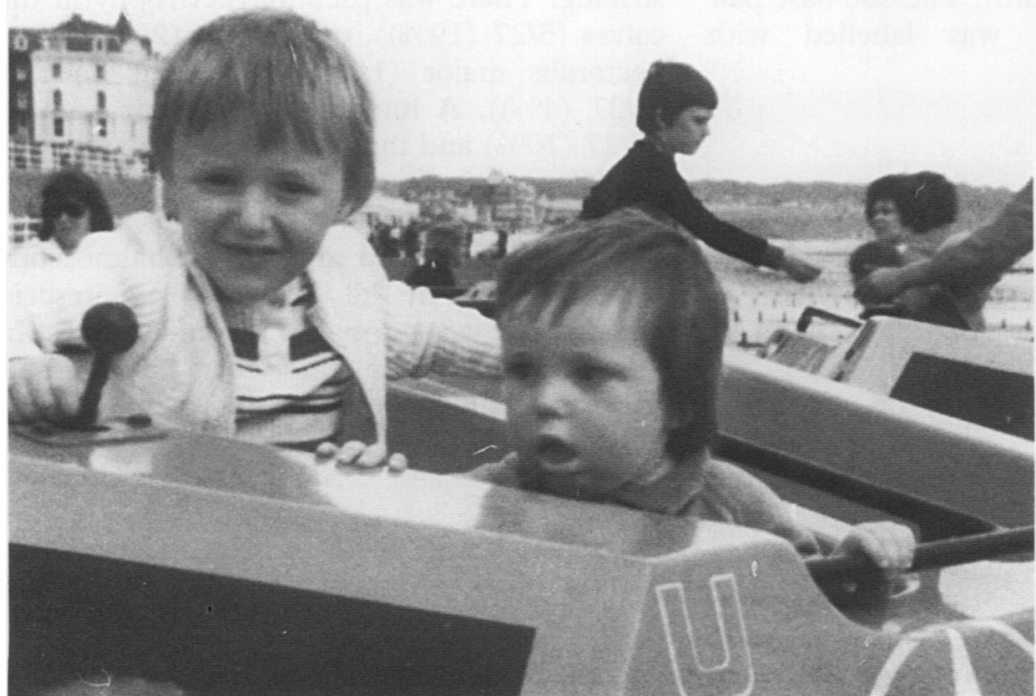

Figure 2 Aged 2.5 years: a diagnosis of congenital myotonic dystrophy was made.

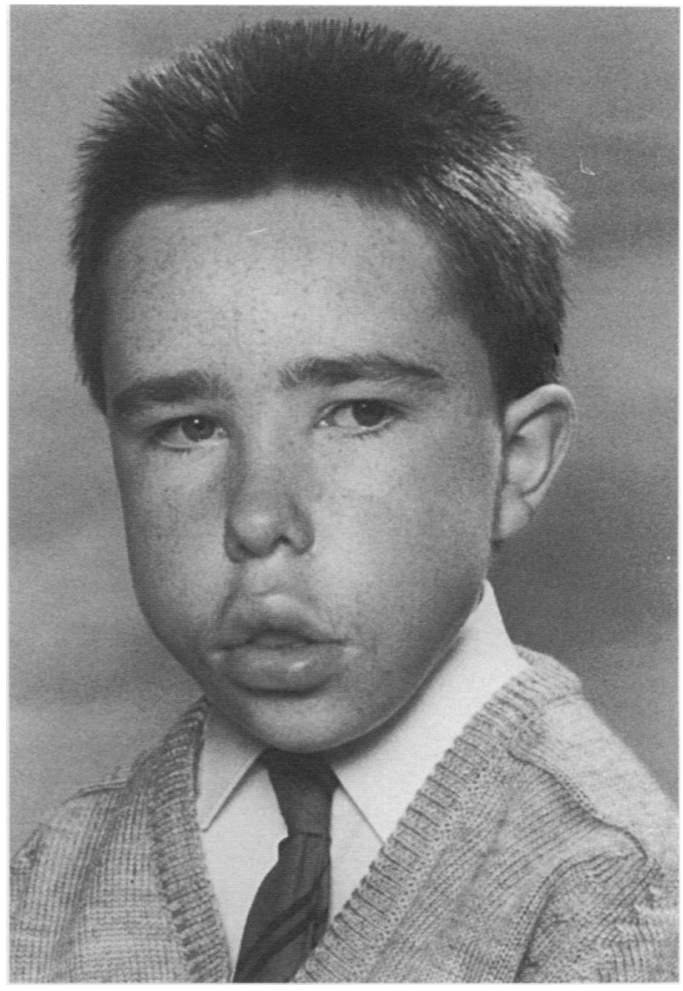

Figure 3 Aged 7 years: everted lower lip and almost complete facial immobility.

Medical Research Council grading ${ }^{38}$ was as follows: neck flexion/extension, 5; shoulder abduction to $30^{\circ}, 4-$; elbow flexion, $\mathrm{R} 1, \mathrm{~L} 0$; elbow extension, 1; wrist flexion/extension, 4-; hip flexion/extension, 4; knee flexion/ extension, 4-; ankle dorsiflexion, $\mathrm{R}$ 0, L 4-; and ankle plantar flexion, $\mathrm{R} 1, \mathrm{~L} 4-$. Tendon reflexes were absent. Visual acuity and direct ophthalmoscopy were normal. Intelligence was normal. DNA analysis with p13E-11 showed a new 16 kilobase DNA fragment which was

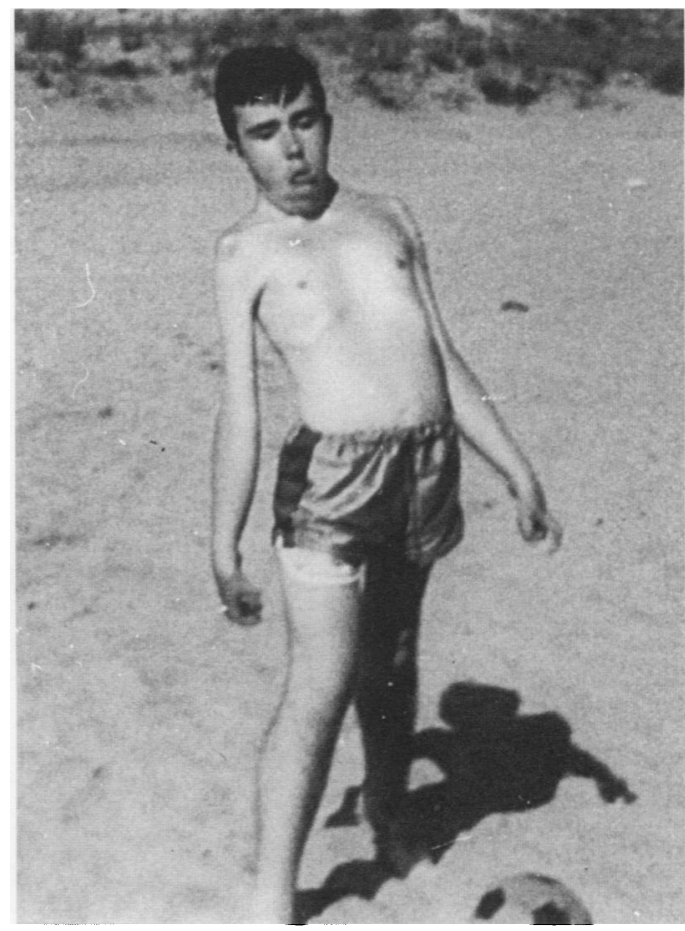

Figure 4 Aged 10 years: wasting of the pectorals, deltoids, and upper arm muscles with a marked lumbar lordosis and calf pseudohypertrophy. 


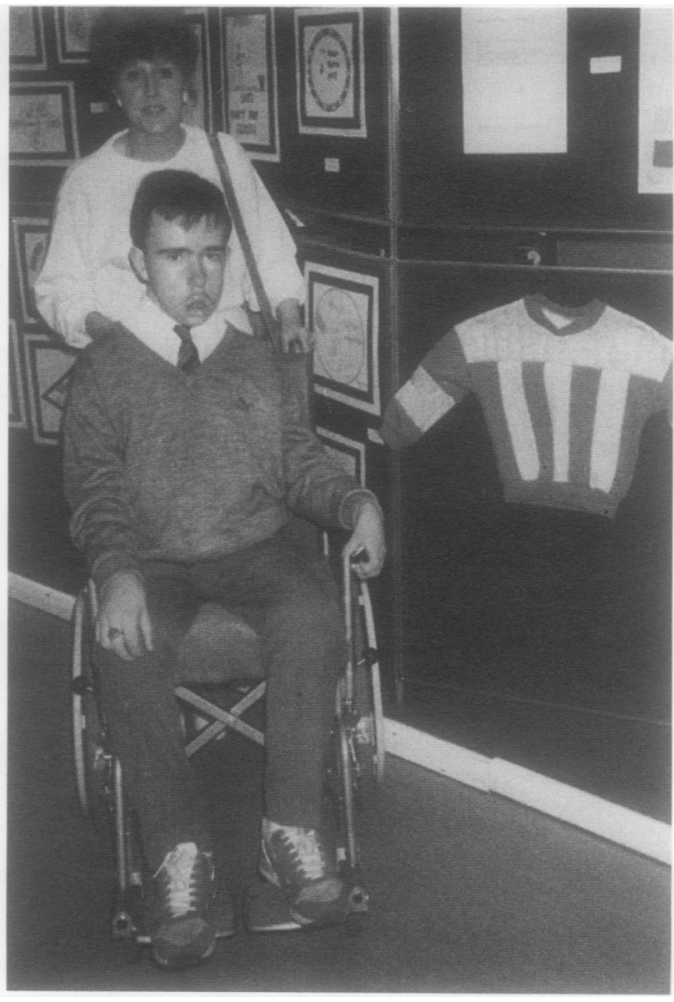

Figure 5 Aged 11 years: an electric wheelchair was needed. Normal facial appearance in mother.

not present in either his parents or brother (fig 6).

\section{LABORATORY METHODS}

The study received local ethical committee approval in Bristol and Marburg. Lymphocyte DNA was extracted from the index patient and both parents by standard methods. High resolution karyotyping was performed on the Bristol patients. The laboratory methods did not differ between the two centres. A $10 \mu \mathrm{g}$ sample of genomic DNA was digested with EcoR1 and separated on a $0.5 \%$ agarose gel for 48 hours at $0.5 \mathrm{~V} / \mathrm{cm}$. High molecular weight markers (Gibco. BRL) were used for sizing the fragments. The DNA on the gel was irradiated with $260 \mathrm{~nm}$ ultraviolet light for 60 seconds and was then Southern blotted onto Hybond $\mathrm{N}$ membranes (Amersham). The 800 base pair insert from p13E-11 was labelled with phosphorus-32 using primer extension ${ }^{39}$ and hybridised at $65^{\circ} \mathrm{C}$. The posthybridisation wash was in $2 \times$ SSC, $0.1 \%$ sodium dodecylsulphate for five minutes at $65^{\circ} \mathrm{C}$, followed by autoradiography for one to seven days at $-70^{\circ} \mathrm{C}$ with an intensifying screen. Details on DNA markers CEB8 (D4F35S1), SBU10 (D4S187), EFD139.1 (D4S184), and pH 30 (D4S139), which were used for haplotyping, have been given previously. ${ }^{32} 40$

\section{Results}

There were 13 boys and 14 girls. All were of normal intelligence. Mean age at onset was $6 \cdot 8$ years (range $<1$ year to 16 years). The mean age at examination was 24.5 years (range 7-50 years). The presenting symptom (table 2 ) was facial weakness (facial asymmetry, facial diplegia, infantile sucking difficulties, indistinct speech, drooling) in $13 / 27(48 \%)$, shoulder girdle weakness (scapular winging or weakness of shoulder abduction) in 9/27 (33\%), leg weakness (limp or abnormal gait) in $4 / 27$ $(15 \%)$, and both shoulder girdle and lower limb weakness in $1 / 27(4 \%)$. In $3 / 27(11 \%)$ there was neonatal hypotonia. Signs of facial weakness were present in all patients and included weakness of eye closure, cheek puff, and inability to whistle or smile. There was often troublesome drooling, particularly at night. There was no extraocular muscle weakness or ptosis. All had scapular winging and weakness of shoulder abduction. Only $2 / 27$ $(7 \%)$ had normal leg power at the ages of 20 and 28 years. A total of $8 / 27(30 \%)$ used wheelchairs at a mean age of $17 \cdot 7$ years (range 8-37 years) and wheelchair use in the future seemed likely in a further $11 / 27(41 \%)$ who had limited mobility on flat ground and could not climb stairs. A 'descending' pattern of leg involvement was usual (weakness of hip flexors and extensors before anterior tibial and peroneal muscles), but weakness of the two groups at presentation and a 'skip' pattern (anterior tibial and peroneal weakness preceding proximal lower limb weakness) were also described. Asymmetrical wasting and weakness of facial and limb muscles was striking. There was pseudohypertrophy in the calves $(5 / 27(19 \%))$, quadriceps $(2 / 27(7 \%))$, pectoralis major $(1 / 27(4 \%))$, and deltoids $(1 / 27(4 \%))$. A lumbar lordosis was seen in $19 / 27(70 \%)$ and there was a thoracic scoliosis in $9 / 27(33 \%)$. One subject had an operation for scoliosis.

Visual acuity and direct ophthalmoscopy were normal in all patients. Fluorescein angiography was normal in two index cases. In a third index case fluorescein angiograms performed independently of our study were reported as showing 'obvious peripheral

Table 2 Presenting symptom in 27 patients

\begin{tabular}{lc}
\hline Presenting symptom & No (\%) of patients \\
\hline Facial weakness & $13(48)$ \\
Shoulder weakness & $9(33)$ \\
Leg weakness & $4(15)$ \\
Shoulder and leg weakness & $1(4)$ \\
\hline
\end{tabular}




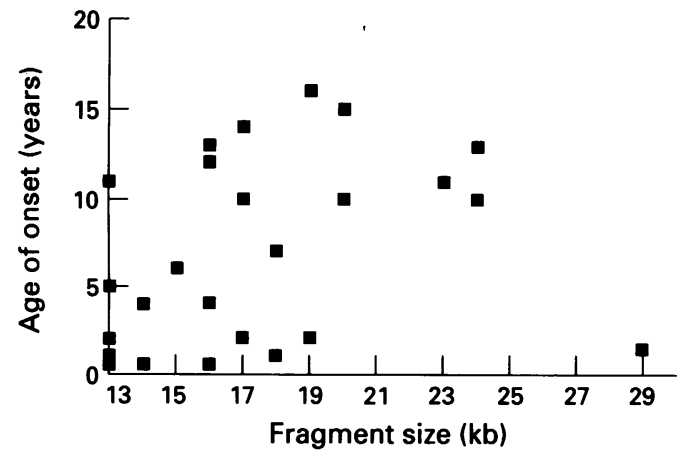

Figure 7 Age of onset versus fragment size. $\mathrm{r}=0 \cdot 291$ (NS).

capillary proliferation'. Similar findings were also seen in the patient's father who was unaffected by clinical and molecular criteria, however, questioning the significance of this report.

There was symptomatic sensorineural deafness with up to $80 \mathrm{~dB}$ loss in $8 / 27(30 \%)$ of patients. Audiograms in two asymptomatic subjects were also abnormal. Muscle biopsy reports were available in $15 / 27(56 \%)$ of patients. A wide variety of abnormalities was reported, including type 2 fibre atrophy (8/15), type 1 fibre atrophy (6/15), fibre necrosis (5/15), type 1 fibre predominance (5/15), fibre hypertrophy (4/15), small angular fibres $(4 / 15)$, 'moth eaten fibres' (3/15), endomysial fibrosis (3/15), inflammatory infiltrate (3/15), marked variation in fibre diameter $(2 / 15)$, and central nuclei (2/15).

Diagnoses made previously in the full sample of 27 patients were congenital facial palsy (two patients), spinal muscular atrophy (two patients), polymyositis (two patients), limb girdle muscular dystrophy (two patients), Becker muscular dystrophy (two patients), mitochondrial myopathy (one patient), Möbius' syndrome (one patient), congenital myotonic dystrophy (one patient), and Sprengel shoulder (one patient). Therefore in over half the patients $(14 / 27)$ the initial diagnosis given was incorrect.

The de novo fragment in the affected patients detected by p13E-11 varied in size from 13 to 29 kilobases (fig 7). No visible chromosome abnormalities were identified. No parental inconsistencies were revealed by haplotyping with polymorphic $4 \mathrm{q} 35$ markers. Patient 15, whose parents were second cousins, did not show any unique clinical features and exhibited a de novo 18 kilobase fragment. The parental consanguinity is assumed to be a non-contributory coincidence.

\section{Discussion}

The presence of $4 \mathrm{q} 35$ rearrangements detected by p13E-11 in children with severe early onset FSHD and the absence of such rearrangements in their parents suggests that the disease has arisen as a new mutation at the FSHD locus. Similar rearrangements are present in sporadic cases with onset in later childhood and adolescence and it seems likely that infantile onset FSHD is part of a continuum of
FSHD as a whole. As a group these 27 new mutation patients are more severely affected than typical familial cases of FSHD, measured, for example, by the greater proportion requiring wheelchairs. This may be due to ascertainment bias but we are also aware of other cases of FSHD, defined clinically, which appear to have arisen from new mutation, but do not show a de novo fragment on Southern blot analysis. These patients tend to have a later age of onset and a milder presentation than the group of 27 presented here. The possibility of a relation between severity/age of onset and the presence of a small de novo fragment cannot yet be dismissed. The presence of questionable facial weakness in two mothers of apparently isolated cases, similar to that described by Brooke et al, ${ }^{27}$ emphasises the caution needed in interpreting facial weakness in FSHD.

Symptomatic facial weakness preceding limb weakness is unusual in FSHD, but may occur. Erroneous diagnoses made at this stage included isolated congenital facial palsy, congenital myotonic dystrophy and Möbius' syndrome. Onset of weakness in the legs has been suggested as excluding the diagnosis of FSHD. ${ }^{41}$ Several parents gave a definite history of onset of leg weakness. As leg weakness is easier to detect in young children than shoulder girdle weakness, the precise sequence of involvement is unclear. A history of onset of weakness in the lower limbs should not exclude the diagnosis of FSHD in a young child. Muscle pseudohypertrophy (hypertrophy with weakness) was noted in only $2 / 107$ (2\%) FSHD patients studied by Padberg. ${ }^{42}$ Interestingly, one of these had onset at the age of 4 years. The finding of pseudohypertrophy in $7 / 27(26 \%)$ in our group suggests that this is a common sign in childhood onset FSHD and should not by itself raise the possibility of Becker muscular dystrophy. ${ }^{36}$

In those patients with leg weakness who were still ambulant there was often a strikingly abnormal gait combined with a severe lumbar lordosis. Spinal bracing in two patients considerably impaired mobility and was soon abandoned. Shapiro et al have suggested that the lordosis helps maintain stability in the presence of gluteus maximus weakness. ${ }^{23}$ Brooke has drawn attention to the social isolation that lack of facial expression, dysarthria, and drooling may cause. ${ }^{27}$ The role of facial surgery in alleviating this is unknown.

The families were uniformly relieved to have a molecular confirmation of the diagnosis, often after many years of diagnostic uncertainty. It is unclear whether life span, which is usually normal in FSHD, will be shortened in this group. Two families have been reported with death in childhood ascribed to FSHD. 4344 In the family reported by Bailey et al early death occurred in boys who were much more severely affected than girls, ${ }^{43}$ raising the possibility of both FSHD and an $\mathrm{X}$ linked dystrophy in this family.

Although sensorineural hearing loss is well described in FSHD, there was often a considerable delay in detecting this. Articulation 
difficulties caused by perioral muscle weakness and undiagnosed deafness sometimes led to indistinct speech and mistakenly low estimates of intelligence. Audiometry should certainly be performed if FSHD is diagnosed in early childhood. Brouwer et al have suggested that high frequency hearing loss is present to some degree in all patients with FSHD. ${ }^{45}$ The finding of asymptomatic high frequency loss in two patients (patients 5 and 15) supports this hypothesis. It has been suggested that this hearing loss may be progressive.

After the reports of Coats' disease and retinal vessel tortuosity in association with FSHD, Fitzsimons et al reported fluorescein angiographic abnormalities in 56/75 (75\%) patients with FSHD. ${ }^{46}$ Shapiro et al suggested that ophthalmological examination would be a useful adjunct to clinical assessment of family members for genetic counselling. ${ }^{23}$ The finding of fluorescein abnormalities in the clinically and molecularly unaffected father of an index patient suggests that these are of doubtful significance and certainly unrelated to FSHD. Fluorescein angiography should not be used as a test for FSHD. As Coats' disease may present at any age, however, all patients with FSHD should have ophthalmoscopy performed and warned to report any visual deterioration. Confirmation that Coats' disease is associated with $4 \mathrm{q} 35$ FSHD and not due to mutation in a different gene will await the demonstration of rearrangement in a patient where this association is observed.

The diagnosis of FSHD should be considered in any child with facial weakness or progressive limb weakness. Neonatal hypotonia, muscle pseudohypertrophy, and sensorineural hearing loss may be present. Where a new mutation can be shown, p13E-11 will be of diagnostic use.

We thank several clinicians, particularly Drs B Reitter, W Schutt, D Thrush, and T Voit, who referred patients. Dr R Frants kindly provided the probe p13E-11. This work was supported by grants from the Association Francaise Contre Les supported by grants from the Association Francaise Contre Les Myopathies, Muscular Dystrophy Group of Great Britain,
South Western Regional Health Authority, Stiftung P E South Western Regional Health
Kempkes, and the Wellcome Trust.

1 Lunt PW, Compston DAS, Harper PS. Estimation of age dependent penetrance in facioscapulohumeral muscular dystrophy by minimising ascertainment bias. 7 Med Genet 1989; 26: 755-60.

2 Lunt PW, Harper PS. Genetic counselling in facioscapulohumeral muscular dystrophy. F Med Genet 1991; 28: 655-64.

3 Duchenne GB. Album de photographies pathologiques. Paris. Baillière, 1862.

4 Landouzy L, Dejerine J. De la myopathie atrophique progressive (myopathie héréditaire débutant, dans l'enfance, par las face, sans altération du système nerveux). Compres Rendus des Séances de l'Acedemie des nerveux). Compres Rend
Sciences 1884; 98: 53-5.

5 Poore GV. Selections from the clinical works of Dr Duchenne. London: New Sydenham Society, 1883.

6 Tyler FH, Stephens FE. Studies in disorders of muscle. II. Clinical manifestations and inheritance of facioscapulohumeral dystrophy in a large family. Ann Intern Med 1950; 32: $640-60$.

7 Walton JN, Gardner-Medwin D. The muscular dystrophies. In: Walton JN, ed. Disorders of voluntary muscle. 5th Ed. Edinburgh: Churchill Livingstone, 1988: 519-68.

8 Small RG. Coats' disease and muscular dystrophy. $\operatorname{Tr} \mathrm{Am}$ Acad Ophth Otol 1968; 72: 225-31

9 Hanson PA, Rowland LP. Möbius syndrome and facioscapulohumeral muscular dystrophy. Arch Neurol 1971; 24: 31-9.

10 Carroll JE, Brooke MH. Infantile facioscapulohumeral dystrophy. In: Serratrice G, Roux H, eds. Perone and related disonders. New York: Masson, 1979: 305-18.
11 Taylor DA, Carrol JE, Smith ME, Johnson MO, Johnston GP, Brooke MH. Facioscapulohumeral dystrophy associated with hearing loss and Coats syndrome. An Neurol 1982; 12: 395-8.

12 Wulff JD, Lin JT, Kepes JJ. Inflammatory facioscapulohumeral muscular dystrophy and Coats syndrome. Ann Neurol 1982; 12: 398-401.

13 Meyerson MD, Lewis E, Ill K. Facioscapulohumeral muscular dystrophy and accompanying hearing loss. Arch Otolaryngol 1984; 110: 261-6.

14 Gurwin EB, Fitzsimons RB, Sehmi KS, Bird AC Retinal telangiectasis in facioscapulohumeral muscular dystrophy with deafness. Arch Ophthalmol 1985; 103: 1695-700.

15 Korf BR, Bresnan MJ, Shapiro F, Sotrel A, Abroms IF. Facioscapulohumeral dystrophy presenting in infancy with facial diplegia and sensorineural deafness. Ann Neurol 1985; 17: 513-6.

16 Gieron MA, Korthals JK, Kousseff BG. Facioscapulohumeral dystrophy with cochlear hearing loss and tortuosity of retinal vessels. Am $\mathcal{F}$ Med Genet 1985; 22: 143-7.

17 Voit T, Lamprecht A, Lenard HG, Goebel HH. Hearing loss in facioscapulohumeral dystrophy. Eur F Pediatr 1986; 145: $280-5$.

18 Matsuzaka T, Sakuragawa N, Terasawa K, Juwabara $H$. Facioscapulohumeral dystrophy associated with mental retardation, hearing loss, and tortuosity of retinal arterioles. $\mathcal{f}$ Child Neurol 1986; 1: 218-23.

19 Yasukohchi S, Yagi Y, Akabane T, Terauchi A, Tamagawa K, Mizuno Y. Facioscapulohumeral dystrophy associated with sensorineural hearing loss, tortuosity of retinal arterioles, and an early onset and rapid progression of respiratory failure. Brain Dev 1988; 10: 319-24.

20 Desai UR, Sabates FN. Long-term follow-up of facioscapulohumeral muscular dystrophy and Coats' disease. Am 7 Ophthalmol 1990; 110: 568-9.

21 Akiyama C, Suzuki H, Nonaka I. A case of facioscapulohumeral muscular dystrophy with infantile spasms, sensorineural deafness and retinal vessel abnormality. No To Hattatsu 1991; 23: 395-9.

22 Shimizu T, Miyamoto $K$, Hayashi $H$, Nagashima $T$, Hirose $K$, Tanabe $H$. Congenital facioscapulohumeral muscular dystrophy associated with tongue atrophy and sensorineural hearing disturbance. Clin Neurol 1991; 31: 433-8.

23 Shapiro F, Specht L, Korf BR. Locomotor problems in infantile facioscapulohumeral muscular dystrophy. Retrospective study of 9 patients. Acta Orthop Scand 1991; 62: 367-71

24 Pauleikhoff D, Bornfeld N, Bird AC, Wessing A. Severe visual loss associated with retinal telangiectasis and facioscapulohumeral muscular dystrophy. Graefes Arch Clin Exp Ophthalmol 1992; 230: 362-5.

25 Fujimura H, Yoshikawa H, Ueno S, Yorifuji S, Tarui S. A case of facioscapulohumeral muscular dystrophy with sensorineural hearing loss and retinal angioma. Clin Neurol 1989; 29: 1387-91.

26 McKusick VA. Mendelian inheritance in man: catalogs of autosomal dominant, autosomal recessive, and $X$-linked phenotypes. 10th Ed. Baltimore, London: Johns Hopkins University Press, 1992.

27 Brooke MH. Facioscapulohumeral dystrophy. In: $A$ clinician's view of neuromuscular diseases. 2nd Ed. Baltimore: Williams and Wilkins, 1986: 158-70.

28 Lecky BRF, MacKenzie JM, Read AP, Wilcox DE. $\mathrm{X}$-linked and FSH dystrophies in one family. Neuromuscular Disorders 1991; 1: 275-8.

29 Wijmenga C, Frants RR, Brouwer OF, Moerer P, Weber JL, Padberg GW. Location of facioscapulohumeral muscular dystrophy gene on chromosome 4. Lancet 1990; 336: $651-3$.

30 Gilbert JR, Stajich JM, Wall S, et al. Evidence for heterogeneity in facioscapulohumeral muscular dystrophy (FSHD). Am f Hum Genet 1993; 53: 401-8.

31 Wijmenga C, Hewitt JE, Sandkuijl LA, et al. Chromosome 4q DNA rearrangements associated with facioscapulohumeral muscular dystrophy. Nature Genet 1992; 2: 26-30.

32 Upadhyaya M, Jardine P, Maynard J, et al. Molecular analysis of British facioscapulohumeral dystrophy families for 4q DNA rearrangements. Human Molecular Genetics 1993; 2: 981-7.

33 Griggs RC, Tawil R, Storvick D, Mendell JR, Altherr MR. Genetics of facioscapulohumeral muscular dystrophy: new mutations in sporadic cases. Neurology 1993; 43: 2369-72.

34 van Deutekom JC, Wijmenga C, van Tienhoven EA, et al. FSHD associated DNA rearrangements are due to deletions of integral copies of a $3.2 \mathrm{~kb}$ tandemly repeated unit. Human Molecular Genetics 1993; 2: 2037-42.

35 Wijmenga C, van Deutekom JC, Hewitt JE, et al. Pulsed field gel electrophresis of the D4F104S1 locus reveals the size and parental origin of the FSHD associated deletions. Genomics 1994; 19: 21-6.

36 Reardon W, Temple IK, Harwood G, Baraitser M. Atypica facio-scapulo-humeral muscular dystrophy - a counselling dilemma. Clin Genet 1991; 39: 172-7.

37 Jardine $\mathbf{P}$, Jones $\mathbf{M}$, Tyfield $L$, Upadhyaya $M$, Lunt $\mathbf{P}$. De novo DNA rearrangement in atypical facioscapulohumeral muscular dystrophy (2). Clin Genet 1993; 44: 167.

38 Medical Research Council. Aids to the examination of the peripheral nervous system. Memorandum No 45 . London
HMSO, 1982. 
39 Feinberg AP, Vogelstein B. A technique for radiolabelling DNA restriction endonuclease fragments to high specific activities. Anal Biochem 1983; 132: 6-13.

40 Upadhyaya M, Lunt P, Sarfarazi M, Broadhead W, Farnham J, Harper PS. The mapping of chromosome 4q markers in relation to facioscapulohumeral muscula dystrophy (FSHD). Am $\mathcal{f}$ Hum Genet 1992; 51: 404-10.

41 Padberg GW, Lunt PW, Koch M, Fardeau M. Diagnostic criteria for facioscapulohumeral muscular dystrophy. Neuromuscular Disorders 1991; 1: 231-4.

42 Padberg G. Facioscapulohumeral disease [Thesis]. Leiden: University of Leiden, 1982.
43 Bailey RO, Marzulo DC, Hans MB. Infantile facioscapulohumeral muscular dystrophy: new observations. Acta Neurol Scand 1986; 74: 51-8.

44 McGarry J, Garg B, Silbert S. Death in childhood due to facio-scapulo-humeral dystrophy. Acta Neurol Scand 1983; 68: 61-3.

45 Brouwer, OF, Padberg GW, Ruys CJ, Brand R, de Laat JA, Groote JJ. Hearing loss in facioscapulohumeral muscular dystrophy. Neurology 1991; 41: 1878-81.

46 Fitzsimons RB, Gurwin EB, Bird AC. Retinal vascular abnormalities in facioscapulohumeral muscular dystrophy: a general association with genetic and therapeutic implications. Brain 1987; 110: 631-48. 